\title{
Gonadotrophin secretion during the periovulatory period in Galway and Finnish Landrace ewes and Finnish Landrace ewes selected for high ovulation rate
}

\author{
T. E. Adams, J. F. Quirke*†, J. P. Hanrahan*, B. M. Adams and \\ J. G. Watson \\ Department of Animal Science, University of California, Davis, CA 95616, U.S.A. and \\ *The Agricultural Institute Grange, Dunsany, Co. Meath, Ireland
}

\begin{abstract}
Summary. Rates of ovulation differed significantly $(P<0.01)$ among ewes of the different genetic lines. However, of the reproductive characteristics studied, only progesterone concentration at the height of luteal function, duration of oestrus, and interval from onset of oestrus to peak of the preovulatory gonadotrophin surge showed significant positive association with rate of ovulation. The pattern of secretion of $\mathrm{LH}$ during the periovulatory period did not differ in the Galway and Finnish Landrace breeds. The total amount of LH secreted during the preovulatory surge did not differ amongst lines. Similarly, no difference in the plasma concentration of $\mathrm{LH}$ at the height of the preovulatory surge was noted among Galway and reference Finnish Landrace lines. However, the concentration of $\mathrm{LH}$ at the height of the surge was significantly $(P<0.05)$ reduced in the selected Finnish Landrace line. Plasma concentrations of FSH during the preovulatory period were significantly $(P<0.05)$ elevated in the breed (Galway) with the lowest prolificacy. When contrasted with either of the Finnish Landrace lines, the magnitudes of the preovulatory surge of FSH and the secondary surge of FSH were significantly greater $(P<0.05)$ in Galway ewes. These results suggest that genetic difference in rate of ovulation among sheep breeds is not tightly coupled to quantitative differences in plasma concentration of gonadotrophic hormones during the periovulatory period.
\end{abstract}

Keywords: gonadotrophins; periovulatory period; ovulation rate; prolific sheep

\section{Introduction}

Maturation of preovulatory follicles and ovulation are the product of a complex interplay between ovarian, hypophysial, and hypothalamic inputs (Baird, 1983; Driancourt et al., 1985). Follicle recruitment and development leading to ovulation can be increased by manipulation of these hormonal inputs. Thus, ovulation rate can be augmented by immunoneutralization of the ovarian hormones inhibin (Henderson et al., 1984) and androstenedione (Quirke et al., 1986; Scaramuzzi et al., 1977) or by administration of FSH (Wright et al., 1981). However, the physiological correlates that determine the differential rates of ovulation in breeds of sheep that differ in prolificacy are not clearly defined. Although elevated secretion of LH during the preovulatory period is essential for proper follicle development and ovulation (McNatty et al., 1981), no consistent association has been noted between the pattern of secretion of plasma concentration of $\mathrm{LH}$ during the preovulatory period and rate of ovulation among sheep breeds that differ in prolificacy (Bindon et al.,

$\dagger$ Present address: Boehringer Ingelheim Vedmedica, 6507 Ingelheim am Rhein, Postfach 200, West Germany. 
1979; Cahill et al., 1981; Lahlou-Kassi et al., 1984). Similarly, the relationship between serum concentrations of FSH during the periovulatory period and rate of ovulation is ambiguous. The D'Man, a prolific Moroccan breed, displays augmented FSH secretion during the preovulatory period when compared with the less prolific Timahdite breed (Lahlou-Kassi et al., 1984). In contrast, no consistent enhancement of FSH secretion was evident during the preovulatory period in the Romanov breed, when compared to FSH patterns in less prolific breeds (Bindon et al., 1979; Cahill et al., 1981). However, Cahill et al. (1981) observed that the secondary increase in FSH secretion following the preovulatory gonadotrophin surge was augmented in Romanov ewes relative to ewes of the less prolific Ile-de-France breed. Similarly, McNatty et al. (1985) have reported that plasma concentrations of FSH during the late luteal phase in Romney ewes were significantly higher in ewes that ovulated two ova during the subsequent periovulatory period when contrasted with ewes that released a single ovum. In comparison with the standard Merino, pituitary content of FSH, but not $\mathbf{L H}$, is significantly augmented in ewes of the prolific BooroolaMerino line (Robertson et al., 1984). In addition, plasma concentrations of FSH during the periovulatory period are significantly higher in the Booroola-Merino than in the standard Merino (McNatty et al., 1987).

The objectives of the present study were to examine the patterns of secretion of $\mathrm{LH}, \mathrm{FSH}$ and progesterone during the periovulatory period in Galway and Finnish Landrace ewes, two breeds that differ markedly in natural ovulation rate (Hanrahan \& Quirke, 1975, 1985). In addition, the same hormones were examined in a random sample of Finnish Landrace ewes from a line that had been selected for increased ovulation rate since 1976.

\section{Materials and Methods}

Animals. Individuals from populations that differed markedly in rate of ovulation were used. Specifically, 7 Galway and 21 Finnish Landrace ewes, aged 3-5 years, were used: 10 of the Finnish Landrace ewes were drawn at random from a line under genetic selection for increased ovulation rate since 1976, with the remainder of the Finnish Landrace ewes obtained from the control flock in that selection experiment. At the start of the present study the estimated genetic difference in ovulation rate between these lines was greater than one ovum per cycle for mature ewes (Hanrahan, 1984). All animals were allowed free access to hay and water and had a daily allowance of concentrates.

Treatment. Reproductive activity was synchronized in all ewes by insertion of vaginal pessaries impregnated with $40 \mathrm{mg}$ of the synthetic progestagen, cronolone (Chrono-gest, Intervet S.A., France). Pessaries were inserted on 5 October and allowed to remain in place for 14 days. Vasectomized rams carrying marking harnesses were introduced into the flock of experimental animals at the time of pessary removal and the ewes were inspected twice daily for 5 days for evidence of mating. Ovulation rate during the synchronized oestrus was assessed by endoscopy 7 days (26 October) after pessary removal.

Sample collection. Daily blood samples were collected by jugular venepuncture beginning 7 days after pessary removal (26 October) and continuing for the next 24 days. More intensive blood collection (6 times daily at 4-h intervals) was started at $14: 00 \mathrm{~h}$ on 2 November ( 15 days after pessary removal). In addition, expression of behavioural oestrus (willingness to stand immobile during mounting by a vasectomized ram) was evaluated at 4-h intervals beginning at 15:00 h on 2 November. At the first sign of oestrus, the frequency of evaluation for oestrus was increased to 12 times daily at 2 - $\mathrm{h}$ intervals and continued at that frequency for $6 \mathrm{~h}$ after the last sign of overt oestrus display. Intensive blood collection (4-h intervals) was continued through, and for $24 \mathrm{~h}$ after, oestrus. Blood samples were stored on ice until centrifugation, at which time the plasma was harvested, frozen, and stored at $-20^{\circ} \mathrm{C}$ for later hormone assays. The rate of ovulation during the first oestrus after the synchronized oestrus was determined by endoscopy 23 days (11 November) after pessary removal.

Hormone assays. Plasma concentrations of $\mathrm{LH}$ and progesterone were evaluated by established radioimmunoassay procedures (Adams et al., 1975; Gibori et al., 1977). Immunoreactive LH was evaluated relative to the NIAMDD-oLH-23 standard preparation. The buffer system used for the LH radioimmunoassay was $0 \cdot 1 \%$ gelatin$0 \cdot 1 \mathrm{M}$-phosphate-buffered saline (Gel-PBS). Plasma volumes assayed by this method ranged from 20 to $200 \mu \mathrm{l}$, depending on the concentration of LH contained in the sample. Intra- and inter-assay coefficients of variation for this assay were $7 \cdot 1 \%$ and $8 \cdot 1 \%$, respectively. The minimum sensitivity of the $\mathrm{LH}$ radioimmunoassay was $100 \mathrm{pg} / \mathrm{ml}$. The radioimmunoassay for progesterone used crystalline progesterone as reference preparation. This assay had a minimum sensitivity of $100 \mathrm{pg} / \mathrm{ml}$ and intra- and inter-assay coefficients of variation of $8.2 \%$ and $10 \cdot 5 \%$, respectively.

The procedure for progesterone radioimmunoassay, in brief, involved extraction of plasma samples in duplicate with 40 volumes of diethyl ether ( $95 \%$ extraction efficiency). The ether extract was evaporated to dryness and 


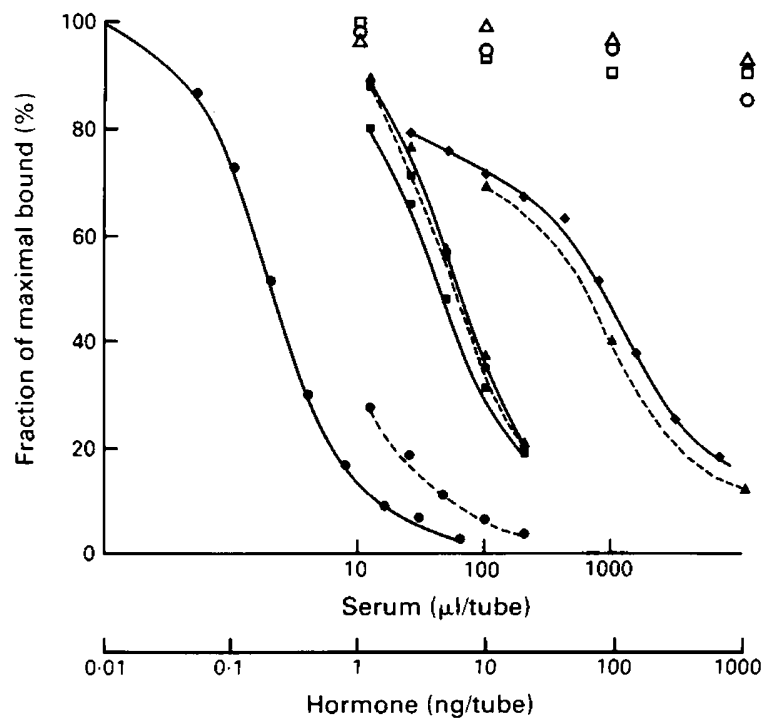

Fig. 1. Specificity and parallelism of the homologous FSH radioimmunoassay. Relative inhibition of binding of radiolabelled sheep FSH during co-incubation with sheep FSH (-O), sheep LH (- ), alpha subunit of sheep LH (-- $-\Delta)$, sheep prolactin $(\triangle)$, hCG $(\square)$ or GnRH $(O)$, was taken as a measure of specificity. Inhibition of binding during co-incubation with increasing volumes of plasma from ovariectomized $(---0)$ or anoestrous $(---\square)$ ewes or ewes during the follicular $(-\mathbf{\Delta})$ or luteal (- $\mathbf{\square})$ phases of reproductive cycle was used in evaluation of parallelism.

resuspended in $0.1 \mathrm{ml} \mathrm{Gel-PBS}$ containing 5000 c.p.m. tritiated progesterone. The immunoreaction was started by addition of $0.1 \mathrm{ml}$ antiprogesterone antiserum (GDN No. 337) diluted 1:2600 in Gel-PBS. After incubation at $4^{\circ} \mathrm{C}$ for $24 \mathrm{~h}$ the radioactivity asssociated with the antiserum was determined after addition of dextran-coated charcoal $(0 \cdot 2 \mathrm{ml})$.

Plasma concentrations of FSH were quantified by homologous radioimmunoassay using antibody (NIAMDDanti-oFSH-1), reference preparation (NIAMDD-oFSH-RP-1) and a preparation for iodination (NIAMDD-oFSH-I1) provided by the National Hormone and Pituitary Program (NIDDKD, Bethesda, MD, U.S.A.). The assay buffer used in the FSH radioimmunoassay was Gel-PBS, with incubation volumes and conditions similar to those noted in the general procedures described by Niswender et al. (1969).

Sheep FSH (NIAMDD-oFSH-I-1) was radiolabelled using a modification of the iodination procedure of L'Hermite et al. (1972). Briefly, $1 \mathrm{mCi} \mathrm{Na}{ }^{125} \mathrm{I}$ was added to a serum vial containing $20 \mu \mathrm{g}$ oFSH in $50 \mu \mathrm{l} 0.5 \mathrm{M}$ phosphate buffer ( $\mathrm{pH} 7.5$ ). Iodination was started by addition of $20 \mu \mathrm{g}$ chloramine $\mathrm{T}(2 \mathrm{mg} / \mathrm{ml}$ in $0.05 \mathrm{M}$-phosphate buffer, $\mathrm{pH} 7.5$ ) and allowed to proceed at $25^{\circ} \mathrm{C}$ for $60 \mathrm{sec}$. The reaction was halted by addition of $60 \mu \mathrm{g}$ sodium metabisulphite $(2 \mathrm{mg} / \mathrm{ml}$ in $0.05 \mathrm{M}$-phosphate buffer, $\mathrm{pH} 7.5)$ and immediate chromatography over a column of Sephadex G-25 $(1.0 \times 15.0 \mathrm{~cm})$ eluted with Gel-PBS.

Specificity of the antiserum was evaluated during coincubation with increasing concentrations of sheep FSH (NIAMDD-oFSH-RP-1), sheep LH (NIAMDD-oLH-23) and sheep prolactin (NIAMDD-oPRL-I-1), human chorionic gonadotrophin (hCG; CR 121), gonadotrophin-releasing hormone ( $\mathrm{GnRH}$ ) and the alpha subunit of sheep LH (WWR-1-alpha). As noted in Fig. 1, the anti-oFSH antiserum used in these studies recognized sheep FSH with high affinity but displayed limited cross-reactivity $(<0.35 \%)$ with relatively pure preparations of sheep LH and the alpha subunit of sheep LH. Similarly, the antiserum did not recognize sheep prolactin, hCG or GnRH. In addition, the displacement effected by coincubation with increasing volumes of serum $(12.5-200 \mu \mathrm{l})$ from ovariectomized and anoestrous ewes and from ewes during the luteal and follicular phases of the oestrous cycle paralleled that induced by the FSH standard. Although purified preparations of sheep TSH were not available for use in evaluation of antiserum specificity, serum concentrations of FSH in ovariectomized ewes, as determined by this assay system, were unaffected by intravenous administration of $20 \mu \mathrm{g}$ thyrotrophin-releasing hormone (TRH). The absence of coincident increase in FSH values as measured by radioimmunoassay emphasizes the specificity of the anti-FSH antiserum used in this assay system. The limit of detection of the FSH assay ( $95 \%$ confidence limit of buffer control) was $20 \pm 2 \mathrm{pg} /$ tube, with $50 \%$ inhibition effected by a mass of the FSH standard of $200 \pm 10 \mathrm{pg} /$ tube. Intra- and inter-assay coefficients of variation for the FSH radioimmunoassay were $3 \cdot 2 \%$ and $14 \cdot 1 \%$, respectively. Intra- and inter-assay coefficients of variation were determined using various volumes of a plasma sample containing a concentration of FSH of approximately $20 \mathrm{ng} / \mathrm{ml}$. The sample volume used in the FSH radioimmunoassay was $100 \mu \mathrm{l}$ plasma. 
Data analysis. The measures of plasma concentrations of LH, FSH and progesterone during the periovulatory period for each ewe were arranged relative to the time during the preovulatory surge when plasma LH was maximal (time 0). Following such arrangement, differences in hormone characteristics between genetic groups were evaluated by analysis of variance for repeated measures and mean comparisons were made using Bonferoni's test (Gill, 1978). Other measures of reproductive function (length of oestrus, interval between onset of oestrus and preovulatory gonadotrophin surge and ovulation rate) were evaluated by one-way analysis of variance. The area under the profiles of plasma concentration of LH and FSH during the periovulatory period was calculated for each animal using a computer program that integrates hormone concentration over time. In these calculations basal hormone concentration was defined as the concentration at the beginning of the integrative period. For purposes of statistical analysis, luteolysis was considered complete when the plasma concentration of progesterone fell below $0.5 \mathrm{ng} / \mathrm{ml}$. Similarly, the plasma concentration of progesterone $96 \mathrm{~h}$ before the preovulatory surge of gonadotrophin was taken as a measure of maximal luteal activity. Plasma progesterone is maximal at this point in the oestrous cycle of Finnish Landrace and Galway ewes (Quirke et al., 1979) and ewes of other breeds that differ markedly in ovulation rate (Cahill et al., 1981).

\section{Results}

\section{Ovulation and oestrus}

The quantitative character of hormone secretion during the second periovulatory period after synchronization of oestrus in Galway and Finnish Landrace ewes, and Finnish Landrace ewes selected for high ovulation rate is detailed below (Fig. 2). The number of ova shed and duration of oestrus during this particular periovulatory period varied significantly between the three genetic groups studied (Table 1). Finnish Landrace ewes from the control flock had a higher ovulation rate and longer duration of oestrus than did ewes of the Galway breed $(P<0.01)$. Similarly, ewes from the line of Finn sheep selected for high ovulation rate had a higher ovulation rate and more extended oestrus than did Galway or unselected Finnish Landrace ewes $(P<0.05)$. Although the interval from onset of oestrus to the peak of the preovulatory gonadotrophin surge did not differ between the two groups of Finnish Landrace ewes, this interval was significantly $(P<0.001)$ shorter in ewes of the Galway breed (Table 1).

Table 1. Ovulation rate, duration of oestrus, and interval from onset of oestrus to peak of preovulatory gonadotrophin surge in sheep lines that vary in prolificacy

\begin{tabular}{|c|c|c|c|c|c|}
\hline \multirow[b]{2}{*}{ Group } & \multirow{2}{*}{$\begin{array}{c}\text { No. of } \\
\text { ewes }\end{array}$} & \multicolumn{2}{|c|}{ Ovulation rate } & \multirow{2}{*}{$\begin{array}{l}\text { Duration of } 2 \text { nd } \\
\text { oestrus } \\
\text { (h) }\end{array}$} & \multirow{2}{*}{$\begin{array}{l}\text { Interval of } \\
\text { oestrus-LH peak } \\
\text { (h) }\end{array}$} \\
\hline & & 1st cycle* & 2nd cyclet & & \\
\hline Galway & 7 & $1.7 \pm 0.2^{a}$ & $2 \cdot 3 \pm 0 \cdot 2^{a}$ & $34 \cdot 0 \pm 3 \cdot 2^{a}$ & $4 \cdot 1 \pm 1 \cdot 1^{\mathrm{a}}$ \\
\hline Finnish Landrace & 11 & $3.6 \pm 0.4^{b}$ & $3 \cdot 6 \pm 0 \cdot 2^{b}$ & $45 \cdot 6 \pm 2 \cdot 7^{b}$ & $11 \cdot 2 \pm 0 \cdot 8^{b}$ \\
\hline $\begin{array}{l}\text { Selected } \\
\text { Finnish Landrace }\end{array}$ & 10 & $4.9 \pm 0.9^{b}$ & $5 \cdot 1 \pm 0 \cdot 5^{\mathrm{c}}$ & $53 \cdot 6 \pm 3 \cdot 0^{c}$ & $12 \cdot 2 \pm 1 \cdot 0^{\mathrm{b}}$ \\
\hline $\begin{array}{l}\text { Significance of } \\
\text { differences }\end{array}$ & & $P<0.05$ & $P<0.01$ & $P<0.05$ & $P<0.001$ \\
\hline
\end{tabular}

Values are mean \pm s.e.m.

*Ovulation rate during synchronized oestrus.

fOvulation rate during second oestrus period.

${ }_{\mathrm{a}, \mathrm{b}, \mathrm{c}}$ Within-column values with different superscripts differ significantly $(P<0.05)$.

\section{Hormone characteristics}

The temporal patterns of secretion of LH, FSH and progesterone during the periovulatory period are presented in Fig. 2.

Progesterone. When contrasted with ewes of the Galway breed (Table 2), both lines of Finnish Landrace ewes displayed higher plasma concentrations of progesterone $(P<0.05)$ at the height of luteal function ( $96 \mathrm{~h}$ before the preovulatory surge of gonadotrophin). Plasma progesterone concentration at the height of luteal function did not differ significantly between lines of Finnish 


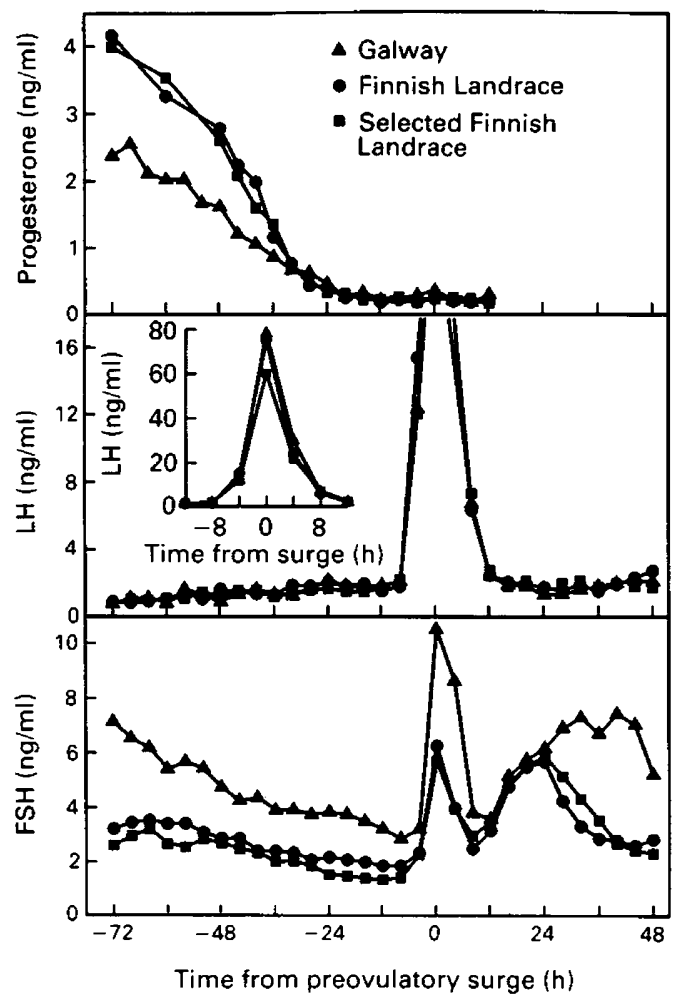

Fig. 2. Mean plasma concentrations of LH, FSH and progesterone during the periovulatory period in Galway $(\mathrm{N}=7)$ and Finnish Landrace $(\mathrm{N}=11)$ ewes and Finnish Landrace ewes from a line selected for high ovulation rate $(\mathrm{N}=10)$.

Landrace ewes (Table 2). Although the maximal plasma concentration of progesterone differed significantly among Galway and Finnish Landrace groups, the temporal pattern of luteolysis, expressed relative to the time of the preovulatory gonadotrophin surge, was similar among the genetic lines examined. The interval from completion of luteolysis to the preovulatory surge of gonadotrophin did not vary among groups. Completion of luteolysis was evident $28 \cdot 0 \pm 3 \cdot 1 \mathrm{~h}$, $29.8 \pm 1.6 \mathrm{~h}$ and $29.2 \pm 1.7 \mathrm{~h}$ before the gonadotrophin surge in Galway, Finnish Landrace and selected Finnish Landrace groups, respectively.

$L H$. The pattern of $\mathrm{LH}$ secretion during the $72-\mathrm{h}$ period leading to the preovulatory surge of gonadotrophin did not differ among the three genetic lines examined. In the Galway and both Finnish Landrace lines, plasma concentrations of $\mathrm{LH}$ increased 2-fold during this 72-h period. Similarly, the plasma concentrations of LH did not differ among lines during this interval. In addition, no difference among the genetic lines was noted in the total LH secreted during the preovulatory surge (Tables $2 \& 3$ ). Although no difference in the plasma concentration of LH at the peak of the surge was noted among Galway and reference Finnish Landrace lines, values were significantly $(P<0.05)$ reduced in the Finnish Landrace line selected for high ovulation rate.

$F S H$. Although the general pattern of secretion of FSH during the periovulatory period did not differ among genetic groups, significant differences were noted in the plasma concentrations of FSH during this period. In all animals, plasma concentrations of FSH declined by $50 \%$ during the 72-h period leading to the preovulatory surge of gonadotrophin. However, plasma concentrations of FSH in Galway ewes were 2-fold higher than FSH concentrations in either of the Finnish Landrace lines throughout this period. Similarly, both the plasma concentration of FSH at the 
Table 2. Plasma concentration of LH and FSH at the peak of the preovulatory gonadotrophin surge and plasma concentration of progesterone $96 \mathrm{~h}$ before the preovulatory gonadotrophin surge

\begin{tabular}{lcccc}
\hline Breed & $\begin{array}{c}\text { No. } \\
\text { of ewes }\end{array}$ & $\begin{array}{c}\text { LH } \\
(\mathrm{ng} / \mathrm{ml})\end{array}$ & $\begin{array}{c}\text { FSH } \\
(\mathrm{ng} / \mathrm{ml})\end{array}$ & $\begin{array}{c}\text { Progesterone } \\
(\mathrm{ng} / \mathrm{ml})\end{array}$ \\
\hline Galway & 7 & $78 \cdot 1 \pm 13 \cdot 4^{\mathrm{a}}$ & $10 \cdot 5 \pm 1 \cdot 8^{\mathrm{a}}$ & $3 \cdot 2 \pm 0 \cdot 5^{\mathrm{a}}$ \\
Finnish Landrace & 11 & $75 \cdot 2 \pm 7 \cdot 5^{\mathrm{a}}$ & $6 \cdot 3 \pm 1 \cdot 1^{\mathrm{b}}$ & $4 \cdot 7 \pm 0 \cdot 3^{\mathrm{b}}$ \\
Selected & 10 & $60 \cdot 2 \pm 5 \cdot 8^{\mathrm{a}}$ & $5 \cdot 7 \pm 0 \cdot 7^{\mathrm{b}}$ & $5 \cdot 0 \pm 0 \cdot 4^{\mathrm{b}}$ \\
Finnish Landrace & & &
\end{tabular}

Values are mean \pm s.e.m.

${ }^{\mathrm{a}, \mathrm{b}}$ Within-column values with different superscripts differ significantly $(P<0.05)$.

Table 3. Total LH and FSH secretion during the preovulatory gonadotrophin surge and total FSH secretion during the secondary FSH surge

\begin{tabular}{lcccc}
\hline & \multirow{2}{*}{$\begin{array}{c}\text { No. of } \\
\text { Bweed }\end{array}$} & \multicolumn{2}{c}{ Preovulatory surge } & \multirow{2}{*}{$\begin{array}{c}\text { Secondary surge } \\
\text { of FSH }{ }^{*}\end{array}$} \\
\cline { 3 - 4 } & 10 & $526 \cdot 8 \pm 78 \cdot 7^{\mathrm{a}}$ & $130 \cdot 1 \pm 18 \cdot 6^{\mathrm{a}}$ & $228 \cdot 4 \pm 39 \cdot 8^{\mathrm{a}}$ \\
Galway & 11 & $499 \cdot 0 \pm 82 \cdot 6^{\mathrm{a}}$ & $78 \cdot 1 \pm 7 \cdot 7^{\mathrm{b}}$ & $139 \cdot 1 \pm 17 \cdot 0^{\mathrm{b}}$ \\
Finnish Landrace & 10 & $436 \cdot 3 \pm 30 \cdot 1^{\mathrm{a}}$ & $75 \cdot 3 \pm 4 \cdot 8^{\mathrm{b}}$ & $149 \cdot 1 \pm 11 \cdot 5^{\mathrm{b}}$ \\
Selected & & & &
\end{tabular}

Values are mean \pm s.e.m.

*Area under the plasma concentration profile for the 24 -h period beginning $12 \mathrm{~h}$ before the peak of the preovulatory surge $(\mathrm{ng} / \mathrm{ml} / 24 \mathrm{~h})$.

†Area under the plasma concentration profile for the 36-h period beginning $12 \mathrm{~h}$ after the peak of the preovulatory surge $(\mathrm{ng} / \mathrm{ml} / 36 \mathrm{~h})$.

${ }^{\mathrm{a}, \mathrm{b}}$ Within column values with different superscripts differ significantly $(P<0.05)$.

peak of the preovulatory surge (Table 2) and the total amount of FSH secreted during the surge (Table 3) were significantly greater in the Galway breed than either of the Finnish Landrace lines $(P<0.05)$. A secondary elevation of plasma FSH was evident in all ewes $12-48 \mathrm{~h}$ after the preovulatory gonadotrophin surge. The magnitude of the preovulatory surge of FSH and the pattern of secretion and concentration of plasma FSH did not differ between Finnish Landrace lines. Similarly, no difference was evident among Finnish Landrace lines in the magnitude of total FSH secreted during the secondary FSH surge. In contrast, these parameters were significantly $(P<0.05)$ greater in Galway ewes than in the more prolific Finnish Landrace lines.

\section{Discussion}

The relative prolificacy of the sheep breeds examined in the study reported here has been well characterized (Hanrahan \& Quirke, 1975, 1985; Hanrahan, 1982). During the specific reproductive cycle examined in detail here, the control and selected lines of Finnish Landrace ewes exhibited rates of ovulation that were similar to those noted previously (Hanrahan, 1984). In contrast, the rate of ovulation noted for the Galway breed $(2 \cdot 3 \pm 0.2 \mathrm{ova} / \mathrm{ewe})$ is $75 \%$ higher than in previous reports. The reason for this unexpectedly high rate of ovulation in the Galway breed is not readily apparent, but may be due to the limited sample size. Indeed, the rate of ovulation in the same 
ewes immediately after synchronization of oestrus was $1.7 \pm 0.2$ ova/ewe, a value more in keeping with previous reports (Hanrahan \& Quirke, 1975, 1985; Quirke et al., 1986). In a previous study (Quirke et al., 1979) we noted that the ovulation rate in Galway ewes at the second oestrus after synchronization was $1.53 \pm 0 \cdot 17$ ova/ewe.

Of the reproductive characteristics examined in this study, only duration of oestrus was positively correlated with differences in ovulation rate between genetic groups. Although progesterone concentration at the height of luteal function and the interval from onset of oestrus to the peak of the preovulatory surge of gonadotrophin differed significantly between ewes of the Galway and Finnish Landrace breeds, these values did not differ between ewes of the two Finnish Landrace lines even though mean ovulation rate in these lines differed by more than 1 ovum per cycle.

The positive relationship between sheep breeds with respect to rate of ovulation and plasma progesterone at the height of luteal function has been noted previously (Quirke et al., 1979; Cahill et al., 1981). Moreover, significant elevation of progesterone secretion during the luteal phase has been noted in ewes of low natural prolificacy in which superovulation was induced by administration of exogenous gonadotrophins (Bindon et al., 1971). This suggests that augmentation of progesterone secretion during the luteal phase in breeds of high prolificacy is likely to be a consequence of, rather than an underlying cause of, high ovulation rate.

The duration of behavioural oestrus in ewes of the prolific Romanov (Bindon et al., 1979) and D'Man (Lahlou-Kassi \& Marie, 1985) breeds is 10-20 h longer than the length of oestrus in less prolific breeds. As reported here, and elsewhere (Land, 1970; Hanrahan \& Quirke, 1975), duration of oestrus in the Finnish Landrace breed is significantly extended compared with less prolific breeds. Similarly, the interval between onset of oestrus and the peak of the preovulatory gonadotrophin surge is significantly extended in ewes of the Romanov breed, a breed with high ovulation rate, compared with sheep of breeds with markedly lower ovulation rates (Land et al., 1973; Cahill et al., 1981). The results presented here, and elsewhere (Quirke et al., 1979), suggest that the same relationship holds for ewes of the Finnish Landrace breed. In contrast, neither duration of oestrus nor interval between onset of oestrus and peak of the preovulatory surge differed between the prolific Booroola-Merino and less prolific Merino lines (Bindon et al., 1984; Bindon \& Piper, 1985).

Both behavioural oestrus and the preovulatory surge of gonadotrophins are driven by the rising tide of oestradiol secretion from the developing Graafian follicles (Scaramuzzi et al., 1971; Karsch et al., 1984). Extension of the interval between onset of behavioural oestrus and the initiation of the gonadotrophin surge in the Finnish Landrace ewes relative to Galway ewes may, therefore, reflect breed differences in hypothalamic or pituitary sensitivity to oestradiol. Indeed, Land (1976) has suggested that sheep breeds characterized by high rates of ovulation are less sensitive to the positive and negative feedback effects of oestradiol than are less prolific breeds.

As noted here, the pattern of secretion of LH during the preovulatory period and the magnitude of the preovulatory surge itself did not differ among the Galway and reference Finnish Landrace lines, breeds that differ significantly in prolificacy (Hanrahan \& Quirke, 1975). These results are consistent with the observations of Webb \& England (1982), who found that the pattern of secretion of LH during the periovulatory period did not differ between Finnish Landrace ewes and ewes of the less prolific Suffolk breed. Similarly, Bindon et al. (1979) and Cahill et al. (1981) reported that plasma concentrations of $\mathrm{LH}$ during the periovulatory period did not differ between ewes of the prolific Romanov and less prolific Ile-de-France breeds. Although quantitative differences in the secretory pattern of LH in Merino and Booroola-Merino lines have not been consistently noted (Bindon et al., 1985), McNatty et al. (1987) have reported that plasma concentrations of $\mathrm{LH}$ during the periovulatory period are significantly higher in the prolific BooroolaMerino line. This increase in plasma LH in the Booroola-Merino is associated with an increase in the amplitude, but not the frequency, of pulsatile LH secretion.

Plasma concentrations of FSH were inversely correlated with ovulation rate in the breeds examined. Plasma concentration of FSH during the preovulatory period and the height and duration of the preovulatory and secondary surges of FSH were significantly augmented in the 
breed with lowest rate of ovulation, the Galway. In contrast, patterns of FSH secretion did not differ between the Finnish Landrace lines that differed significantly in rate of ovulation.

Bindon \& Piper (1985) have suggested that differential patterns of secretion of FSH during the periovulatory period may play a key role in determining genetic differences in ovulation rate. The importance of FSH in this regard is suggested by reports that administration of exogenous FSH markedly increases rate of ovulation in sheep (Wright et al., 1981; McNeilly, 1985). However, the causal link between differential patterns of FSH secretion and genetic difference in ovulation rate has not been unambiguously established. In some sheep breeds of high prolificacy, such as the D'Man (Lahlou-Kassi et al., 1984) and Romanov (Cahill et al., 1981), plasma concentrations of FSH during the preovulatory period, the gonadotrophin surge, and/or the secondary FSH surge that follows within $36 \mathrm{~h}$ of the preovulatory gonadotrophin surge are significantly augmented relative to levels of FSH in breeds of lower prolificacy. In contrast, Webb \& England (1982) reported no significant differences in the serum concentration of FSH during the periovulatory period in Finnish Landrace and Suffolk ewes. Although early studies (Bindon \& Piper, 1982; Bindon et al., 1985) were unable to demonstrate significant differences in the periovulatory profiles of plasma concentrations of FSH in Booroola-Merino and Merino lines, McNatty et al. (1987) have reported that plasma concentrations of FSH during the periovulatory period are consistently elevated in the Booroola-Merino relative to plasma concentrations of FSH at comparable stages of the reproductive cycle in the less prolific standard Merino.

The inconsistent relationship across sheep breeds between prolificacy and plasma concentrations of the gonadotrophins during the periovulatory period suggests that different physiological strategies may have been adopted to affect a common trait, ovulation rate. Certainly the patterns of follicle development show breed-specific variation, even among breeds that are characterized by high rates of ovulation (Driancourt et al., 1986). Thus, the high rate of ovulation in Finnish Landrace ewes is due to limited follicular atresia while the prolificacy of Romanov ewes is ascribed to an increase in the size of the cohort of follicles recruited. In the Booroola-Merino continuous recruitment during the follicular phase is coupled with reduced atresia to effect an enhancement of ovulation rate. Each of these different patterns of folliculogenesis may be driven by different physiological mechanisms, thus leading to inconsistency across breeds in the endocrine correlates associated with high rates of ovulation.

Collectively, the data presented here suggest that genetic difference in rate of ovulation among sheep breeds is not tightly coupled to quantitative differences in serum concentration of gonadotrophic hormones during the periovulatory period. The physiological correlates that underlie genetic difference in rate of ovulation may include variation in ovarian sensitivity to gonadotrophin inputs or variation in the biopotency of gonadotrophic hormones.

We thank Sarah Davis, Debbie Cravin, Emerald Perlas, T. Lally, and W. Loughnane for skilled technical assistance; Dr Samoa Wallach for advice concerning statistical analysis; and Dr G. D. Niswender and Dr T. M. Nett, and the National Hormone and Pituitary Program, National Institutes for Health, for RIA reagents. This research was supported by funding from the EEC Tropical Agriculture Programme (TSD-A-132-IRL), USDA Grant CRCR-1-1870, and the California Agricultural Experiment Station.

\section{References}

Adams, T.E., Kinder, J.E., Chakraborty, P.K., Estergreen, V.L. \& Reeves, J.J. (1975) Ewe luteal function influenced by pulsatile administration of synthetic LHRH/FSHRH. Endocrinology 97, 1460-1467.

Baird, D.T. (1983) Factors regulating the growth of the preovulatory follicle in the sheep and human. $J$. Reprod. Fert. 69, 343-352.
Bindon, B.M. \& Piper, L.R. (1982) Physiological characteristics of high fecundity sheep and cattle. In Proceedings of the World Congress on Sheep and Cattle Breeding, vol. 1, pp. 315-331. Eds R. A. Barton \& W. C. Smith. Dunmore Press, Palmerston North.

Bindon, B.M. \& Piper, L.R. (1985) Booroola $(F)$ gene: 
Major gene affecting ovine ovarian function. In Genetic Engineering of Animals: An Agricultural Perspective, pp.67-93. Eds J. W. Evans \& A. Hollaender. Plenum Press, New York.

Bindon, B.M., Ch'ang, T.S. \& Turner, H.W. (1971) Ovarian response to gonadotrophin by Merino ewes selected for fecundity. Aust. J. agric. Res. 22, 809-820.

Bindon, B.M., Blanc, M.R., Pelletier, J., Terqui, M. \& Thimonier, J. (1979) Periovulatory gonadotrophin and ovarian steroid patterns in sheep of breeds with differing fecundity. J. Reprod. Fert. 55, 15-25.

Bindon, B.M., Piper, L.M. \& Thimonier, J. (1984) Preovulatory LH characteristics and time of ovulation in the prolific Booroola Merino ewe. J. Reprod. Fert. 71, 519-523.

Bindon, B.M., Piper, L.R., Cummins, L.J., O'Shea, T., Hillard, M.A., Findlay, J.K. \& Robertson, D.M. (1985) Reproductive endocrinology of prolific sheep: studies of the Booroola Merino. In Genetics of Reproduction in Sheep, pp. 217-235. Eds R. B. Land \& D. W. Robinson. Butterworths, London.

Cahill, L.P., Saumande, J., Ravault, J.P., Blanc, M., Thimonier, J., Mariana, J.C. \& Mauleon, P. (1981) Hormonal and follicular relationships in ewes of high and low ovulation rates. J. Reprod. Fert. 62, 141-150.

Driancourt, M.A., Gibson, W.R. \& Cahill, L.P. (1985) Follicular dynamics throughout the oestrous cycle in sheep. A review. Reprod. Nutr. Develop. 25, 1-15.

Driancourt, M.A., Gauld, I.K., Terqui, M. \& Webb, R. (1986) Variations in patterns of follicle development in prolific breeds of sheep. J. Reprod. Fert. 78, 565-575.

Gibori, G., Antczak, E. \& Rothchild, I. (1977) The role of estrogen in the regulation of luteal progesterone secretion in the rat after day 12 of pregnancy. Endocrinology 100, 1483-1495.

Gill, J.L. (1978) Design and Analysis of Experiments in the Animal and Medical Sciences. Iowa State University Press, Ames.

Hanrahan, J.P. (1982) Selection for increased ovulation rate, litter size and embryo survival. Proc. 2nd World Congr. Genetics Applied to Livestock Production, Madrid, vol. V, pp. 294-309.

Hanrahan, J.P. (1984) Selection of ovulation rate in Finn Sheep. Animal Production Research Report, pp. 7172. The Agricultural Institute, Dublin.

Hanrahan, J.P. \& Quirke, J.F. (1975) Repeatability of the duration of oestrus and breed differences in the relationship between duration of oestrus and ovulation rate of sheep. J. Reprod. Fert. 45, 29-36.

Hanrahan, J.P. \& Quirke, J.F. (1985) Contribution of variation in ovulation rate and embryo survival to within breed variation in prolificacy. In Genetics of Reproduction in Sheep, pp. 193-201. Eds R. B. Land \& D. W. Robinson. Butterworths, London.

Henderson, K.M., Franchimont, P., Lecomte-Yerna, M.J., Hudson, N. \& Ball, K. (1984) Increase in ovulation rate after active immunization of sheep with inhibin partially purified from bovine follicular fluid. J. Endocr. 102, 305-309.

Karsch, F.J., Bittman, E.L., Foster, D.L., Goodman, R.L. \& Robinson, J.E. (1984) Neuroendocrine basis of seasonal reproduction. Recent Prog. Horm. Res. 40, 185-232.
Lahlou-Kassi, A. \& Marie, M. (1985) Sexual and ovarian function of the D'Man ewe. In Genetics of Reproduction in Sheep, pp. 245-260. Eds R. B. Land \& D. W. Robinson. Butterworths, London.

Lahlou-Kassi, A., Schams, D. \& Glatzel, P. (1984) Plasma gonadotrophin concentrations during the oestrous cycle and after ovariectomy in two breeds of sheep with low and high fecundity. $J$. Reprod. Fert. 70, $165-173$.

Land, R.B. (1970) A relationship between the duration of oestrus, ovulation rate and litter size in sheep. $J$. Reprod. Fert. 23, 49-53.

Land, R.B. (1976) The sensitivity of the ovulation rate of Finnish Landrace and Blackface ewes to exogenous oestrogen. J. Reprod. Fert. 48, 217-218.

Land, R.B., Pelletier, J., Thimonier, J. \& Mauléon, P. (1973) A quantitative study of the genetic differences in the incidence of oestrus, ovulation and plasma luteinizing hormone concentration in sheep. $J$. Endocr. 58, 305-317.

L'Hermite, M., Niswender, G.D., Reichert, L.E. \& Midgley, A.R. (1972) Serum follicle-stimulating hormone in sheep as measured by radioimmunoassay. Biol. Reprod. 6, 325-332.

McNatty, K.P., Gibb, M., Dobson, C. \& Thurley, D.C. (1981) Evidence that changes in luteinizing hormone secretion regulate the growth of the preovulatory follicle in the ewe. $J$. Endocr. 90, 375-389.

McNatty, K.P., Hudson, N., Gibb, M., Ball, K., Henderson, K.M., Heath, D.A., Lun, S. \& Kieboom, L.E. (1985) FSH influences follicle viability, oestradiol biosynthesis and ovulation rate in Romney ewes. $J$. Reprod. Fert. 75, 121-131.

McNatty, K.P., Hudson, N., Henderson, K.M., Gibb, M., Morrison, L., Ball, K. \& Smith, P. (1987) Differences in gonadotrophin concentrations and pituitary responsiveness to GnRH between Booroola ewes which were homozygous (FF), heterozygous $(F+)$ and non-carriers $(++)$ of a major gene influencing their ovulation rate. J. Reprod. Fert. 80, 577-588.

McNeilly, A.S. (1985) Effect of changes in FSH induced by bovine follicular fluid and FSH infusion in the preovulatory phase on subsequent ovulation rate and corpus luteum function in the ewe. J. Reprod. Fert. 74, $661-668$.

Niswender, G.D., Reichert, L.E., Midgley, A.R. \& Nalbandov, A.V. (1969) Radioimmunoassay for bovine and ovine luteinizing hormone. Endocrinology 84, $1166-1173$.

Quirke, J.F., Hanrahan, J.P. \& Gosling, J.P. (1979) Plasma progesterone levels throughout the oestrous cycle and release of $\mathrm{LH}$ at oestrus in sheep with different ovulation rates. $J$. Reprod. Fert. 55, 37-44.

Quirke, J.F., Hanrahan, J.P., Tait, A. \& Kilpatrick, M.J. (1986) Effects of active immunization against androstenedione on ovulation rate and fecundity in Galway and Finnish Landrace sheep. Livestock Prod. Sci. 15, 27-37.

Robertson, D.M., Ellis, S., Foulds, L.M., Findlay, J.K. \& Bindon, B.M. (1984) Pituitary gonadotrophins in Booroola and control Merino sheep. J. Reprod. Fert. 71, 189-197.

Scaramuzzi, R.J., Tillson, S.A., Thorneycroft, I.H. \& Caldwell, B.V. (1971) Action of exogenous progester- 
one and estrogen on behavioral estrus and luteinizing hormone levels in the ovariectomized ewe. Endocrinology 88, $1184-1189$.

Scaramuzzi, R.J., Davidson, W.G. \& Van Look, P.F.A. (1977) Increasing the ovulation rate of sheep by active immunization against an ovarian steroid and androstenedione. Nature, Lond. 269, 817-818.

Webb, R. \& England, B.G. (1982) Identification of the ovulatory follicle in the ewe: associated changes in follicular size, thecal and granulosa cell luteinizing hormone receptors, antral fluid steroids, and circulating hormones during the preovulatory period. Endocrinology 110, 873-881.

Wright, R.W., Bondioli, K., Grammer, J., Kuzan, F. \& Menino, A. (1981) FSH or FSH plus LH superovulation in ewes following estrus synchronization with medoxyprogesterone acetate pessaries. J. Anim. Sci. 52, $115-118$.

Received 18 August 1987 